Journal of Computer Science and Technology Studies (JCSTS))

ISSN: $2709-104 \mathrm{X}$

DOI: $10.32996 / j$ csts

Journal Homepage: www.al-kindipublisher.com/index.php/jcsts

\title{
Information System Engineering for Web-based RPS Adaptation using the Laravel Framework
}

\author{
Gallen Cakra Adhi Wibowo ${ }^{1} \square$ and Eko Sediyono² \\ ${ }^{12}$ Teknik Informatika, Fakultas Teknologi Informasi, Universitas Kristen Satya Wacana, Jl. Diponegoro No.52-60, Salatiga, Kec. \\ Sidorejo, Kota Salatiga, Jawa Tengah 50711
}

$\square$ Corresponding Author: Gallen Cakra Adhi Wibowo, E-mail: gallenbale11@gmail.com

\section{ARTICLE INFORMATION \\ Received: 12 October 2021 \\ Accepted: 17 November 2021 \\ Published: 07 December 2021 \\ DOI: 10.32996/jcsts.2021.3.2.5}

\section{KEYWORDS}

System, rps, laravel, web

\section{ABSTRACT}

Semester Learning Plan (RPS) is a learning planning document that guides lecturers and students to carry out lecture activities for one semester to achieve predetermined learning achievements. that the study program has been determined. RPS is needed to meet and adapt to users' needs because the RPS is regularly reviewed and updated if there are changes in teaching materials that are no longer under current conditions. However, what is often a problem is that the RPS input is still using Microsoft Excel, so that it is not well documented, and the RPS made are not following the material given by the lecturer. Because of these problems, in this study, a web-based RPS adjustment information system will be designed and built using the Laravel framework that can assist the study program in documenting the RPS and knowing the suitability of the material provided by the lecturer's predetermined RPS. The system development method used in this study uses the SDLC method, and its design uses UML (Unified Modeling Language). The final result of this research is a web-based RPS compatibility information system using the Laravel framework, which can facilitate the management of RPS and its compatibility with the material provided by the lecturer.

\section{Introduction}

Semester Learning Plan (RPS) is a learning planning document prepared as a guide for students in carrying out lecture activities for one semester to achieve learning outcomes determined by the program study (Syafarina, 2019) The benefit of having RPS is to guide lecturers and students in the learning process so that the material taught is based on the learning outcomes determined by the study program. In addition, with the RPS, learning achievement standards, learning materials, learning processes, and learning evaluations can be controlled optimally. As well as the variation of the four components caused by differences between one teacher and another can be minimized (Zulkifli, 2013). In the preparation of the RPS, the higher the quality of the RPS will result in more effective and efficient learning and can increase the positive influence on the learning carried out (Muhsinin and Fatmawati, 2020). In order to meet and adapt to the needs of graduate users and the development of science and technology, this lesson plan should be reviewed regularly and updated if there are changes in teaching materials that are no longer in their current state (Nurdin, 2018). RPS is very important to equalize learning standards in the classroom, but no system can monitor the material given by the lecturer whether it is in accordance with the existing RPs. It is essential to be able to monitor and adjust the RPS with the material to be given.

Overcoming these problems, designing a website-based information system using the Laravel framework is a solution that is able to solve various obstacles and challenges faced, digitize the system, and accommodate all stages of RPS implementation to be effective and efficient. This system is built using the Laravel Framework, an open-source framework using the MVC concept (Model, View, Controller) (Aditya, 2019). The Model in Laravel represents a data structure that has functions that can be used to manage the database so that it is easy to create tables and integrate them with the system. View in Laravel is the part that manages the website interface so that users can interact with the application that is created. The controller in Laravel is the part that acts as a bridge between the Model and the view by sending requests from the view and receiving responses from the Model. The web-

Copyright: (c) 2021 the Author(s). This article is an open access article distributed under the terms and conditions of the Creative Commons Attribution (CC-BY) 4.0 license (https://creativecommons.org/licenses/by/4.0/). Published by Al-Kindi Centre for Research and Development, London, United Kingdom. 
based information system is a technology that is currently widely used by various agencies to process data and information. Because by using web-based information system technology, data and information management becomes more effective and efficient (Husaini, 2019). RPS management using a web-based information system will be very helpful for both lecturers as users and study programs as managers. Managers will find it easier to supervise and document lesson plans and lecturers will also have easy access to them anytime and anywhere.

The purpose of this research is to implement the RPS more accurate, effective, and efficient, where inputting the RPS is no longer done manually but can be done in a system so that it can be done in a short time, making it easier for lecturers to manage the RPS, both for entering the RPS and to see its suitability with the material provided and follow up on the results of the RPS can be done more easily and in real-time, documentation from the RPS can be stored digitally. The RPS can be easily implemented for all existing standards in higher education. This system is also expected to be able to visualize the results of the suitability of the RPS, which can be accessed anytime and anywhere so that it can be used as a guide to improving the material provided by the lecturer. The results of this study are expected to be an inspiration, reference, and knowledge for universities and lecturers regarding the implementation of the overall RPS conformity information system. The resulting information system model can be used more broadly because the system design is dynamic and flexible according to user needs.

\section{Literature Review}

Several previous studies are used as references in this study, one of which is a study entitled "Design of Curriculum Instrument Information Systems and Evaluation of Rps Case Study: Information Systems Study Program". This study explained that there were difficulties in preparing the curriculum, which took a long time and must have guidelines with good standards. The purpose of the construction of the system is to speed up the process of designing a curriculum that involves a lot of data, supports the distribution of RPS and materi.Hasil of this study was to produce a system of evaluation instruments and RPS can design a curriculum based on a single standard for a course in information systems as well as the entire course university (Indrawan, 2019).

Another research is "Designing Semester Learning Plan Applications (RPS) to Improve Learning Achievement for Lecturers". In this study, there was a problem, namely the making of RPS still using Microsoft Word, so that the filling point for each variable was a lot different from one another. The information system design process is explained using the case studies method and using stages rather than SDLC. The result of this research is to produce an RPS information system that can make it easier for lecturers to fill in the correct RPS and for faculties to make it easier to record RPS files for accreditation purposes.

Previous research found that making an online RPS system can facilitate study programs in managing and storing RPS files. Therefore, in this study, the application development "Information System for RPS Adjustment Web-based using the Laravel Framework" will be carried out to be able to develop an RPS information system that is not only for managing and storing RPS but can also be used to match the existing RPS with the material provided. by the lecturer.

Laravel Framework is an open source-based programming framework that is used by many developers from around the world (Wijonarko, 2019). The main goal of this framework is for developers to work quickly without the need to rewrite code. The characteristics of Laravel are as follows:

1. Flexible and lightweight so it is easy to learn, modify and integrate the Library and Helper.

2. Using the MVC structure (Model, View, Controller) so that the code is more structured and tidy

3. Having a URL that is easy to understand. Codelgniter reduces the use of \$_GET then replaces it with a URL. 


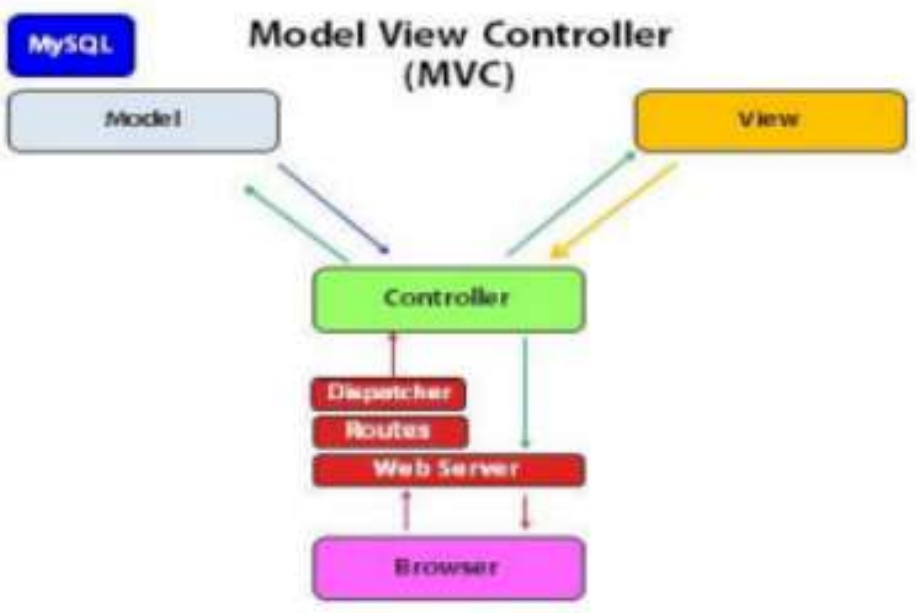

Figure 1 How Laravel Works

In general, Laravel's structure works starting from the browser where the browser will interact with each other through the controller, then the controller receives and replies to all requests from the browser. The controller then requests the Model to get the data, while the user interface requests the view. The outline can be concluded that when the browser accesses the web page, the route will automatically look for the controller in charge of handling the request, then the controller will be used to access the data and the UI.

Laravel's MVC structure is used to separate data access and business logic from user interaction. The separation has been carried out previously so that any changes to data access or business logic do not have a complex impact on the system. MVC separation is a solution that is expected to increase the flexibility and usability of applications.

MVC architecture divides applications into 3 forms: models, views, and controllers. The MVC architecture can be seen in Figure 2.

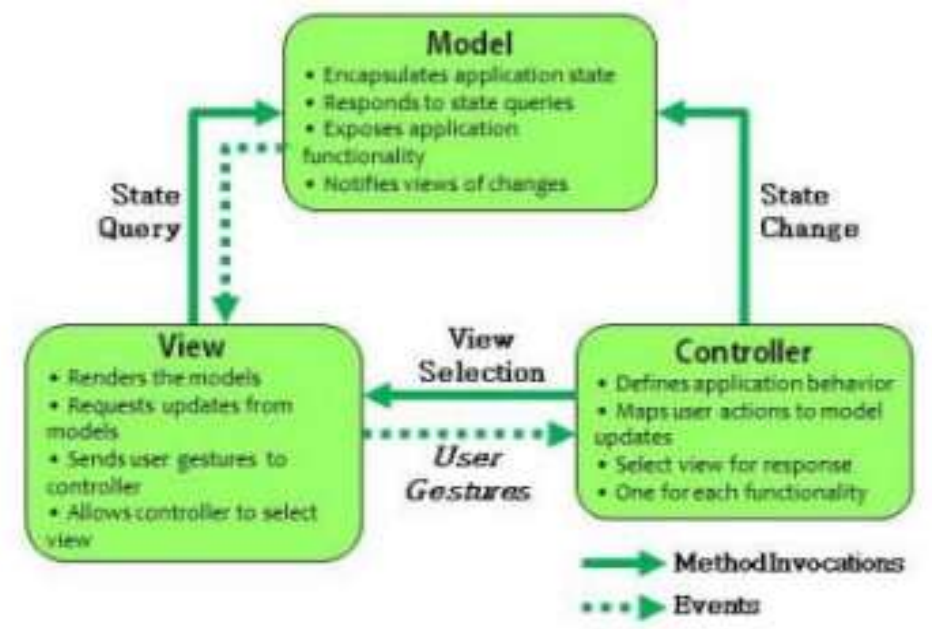

Figure 2 MVC architecture

The Model represents the database including the table design and the relationships that exist in the table. The main function of the Model is to handle data, receive data from the database, enter data into the database, manipulate data through data validation. The view provides the data model and will send activities from the consistency of the display data to the changes that occur. Grouping all displays and presentation codes in one place make it easy to change displays without affecting data access and business logic. The controller defines the behavior that occurs in the application and maps that behavior into actions from the user to the Model. The controller will be closely related to the view because every user interaction related to the display is displayed through the controller. 


\section{Research Methods}

Research and Development (R\&D) is a research method that aims to be used to produce and test the effectiveness of the product or software. The research and development procedure basically consists of two main objectives, namely: (1) developing the product, and (2) testing the effectiveness of the product in achieving the goal. The first objective is referred to as the development function while the second objective is referred to as validation. Thus, the concept of development research is more accurately defined as a development effort that is also accompanied by its validation efforts (Rumetna, 2019).

In this study, data were taken from interviews, observations, literature studies in the development of the system used, namely the Research and Development (R\&D) method which has several stages, namely in Figure 3.

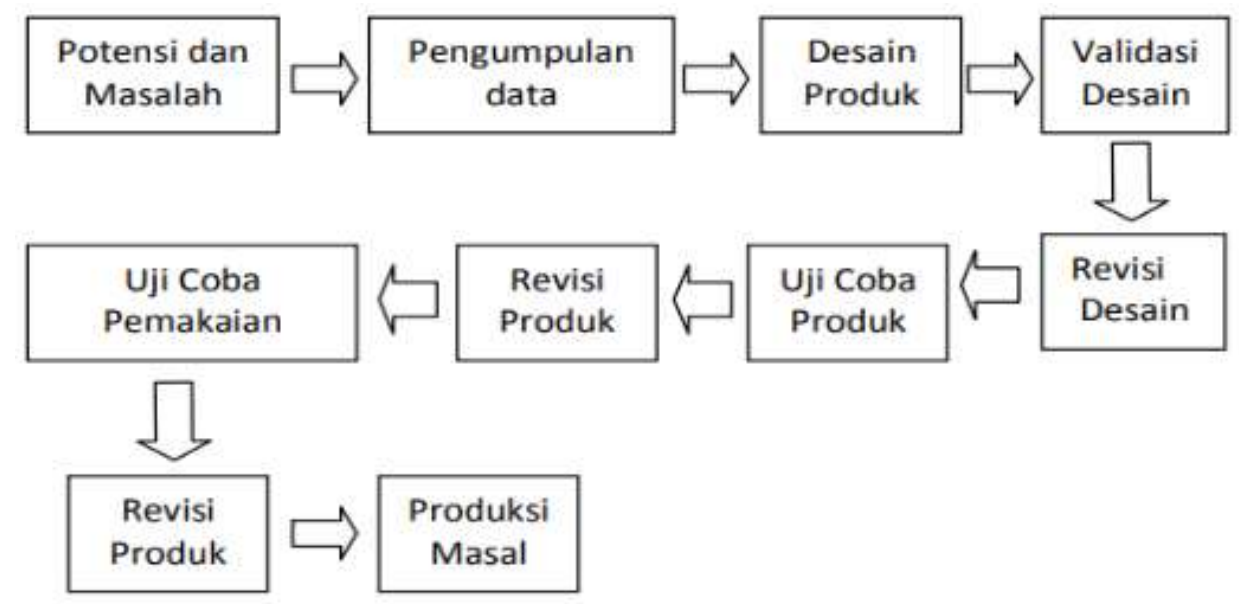

Figure 3 Stages of Research and Development

Stages of Research and Development (R\&D) in This research is as shown in Figure 3 as follows:

A. Potentials and Problems

This research starts from the problem factors that exist in the location and analyzes the needs so that there is a need for the development of a new model. document analysis or reviewing the results of previous research.

B. Data Collection

After the potential and problems can be demonstrated, various information from both lecturers and literature studies can be used as product designs.

C. Product Design

To build a new work system, you have to do a new work design based on an assessment of the performance of the system that is already running, so that deficiencies can be found in the system. The final result of this activity is a new product design, the design to be achieved is a system capable of managing rps and index of adjustment to the given material.

D. Design Validation

After product design, the design validation stage is carried out to assess whether the product design will be more effective than how the system works. Validation here is still an assessment with rational thoughts and responses, which means the product is still in the form of a temporary design.

E. Design Revision

After validation of the design, it will be known the shortcomings. After knowing the shortcomings, the next researcher adds or subtracts the design which is then tested.

F. Product Trial

The product design that has been made cannot be directly tested but must be made first. Produce the product. Testing can be done by comparing the effectiveness and efficiency of the current system with the new system.

G. Trial of Use 
After testing the product and revising it, the product is tested again, and after the product has gone through several tests, the result is a product in the form of a new system, but the product must still be assessed for deficiencies or problems that arise and then be revised further.

H. Product Revision A product revision is carried out, if in the trial use there are problems and deficiencies, this must be adjusted to the needs of the rps adjustment information system.

I. Product Manufacturing This the stage is when the product that has been tested is declared effective and feasible for mass production, in this case, the product is declared useful because it can facilitate the supervision of RPs.

\section{Results and Discussion}

\subsection{Analysis of the proposed system}

To describe a proposed system to explain to the user a good design is needed, as for the methods or design tools using Use Case Diagrams and Class Diagrams. The following is an image of the Use Case Diagram and Class Diagram of the RPS adjustment information system.

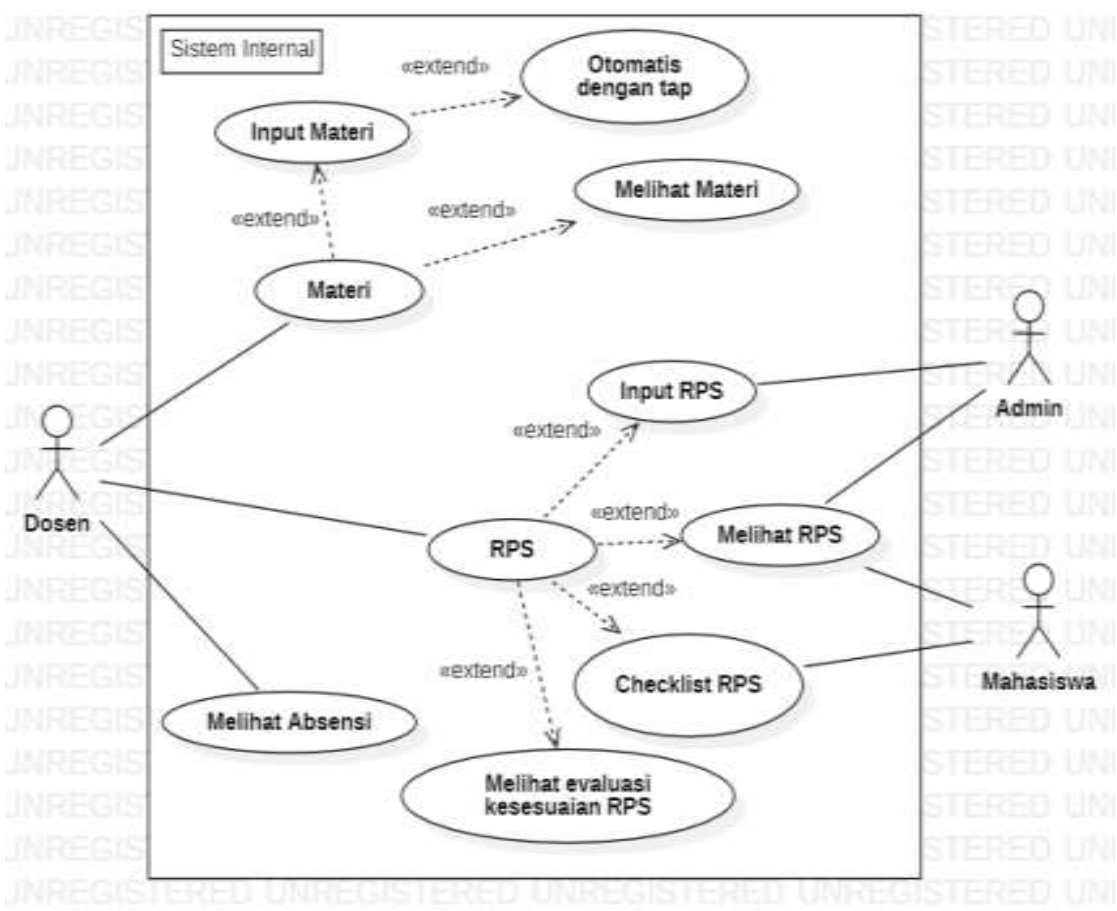

Figure 4 Use Case Diagram

Figure 4 shows that there are three actors in the system, namely admin, lecturers, and students. The three actors have different interactions with the system. Admin can process incoming RPS input on RPS managing interactions. Another interaction admin is able to see RPS existing. DKK admins are only allowed to view RPS data and input because the functions of adding data, deleting data, and updating data are carried out by lecturers. Lecturers can carry out the process of managing material data, RPS, and Viewing attendance. Meanwhile, students can view and check the RPS checklist. Class diagrams describe the interactions between classes and the attributes attached to these classes. The class diagram is shown in Figure 5 


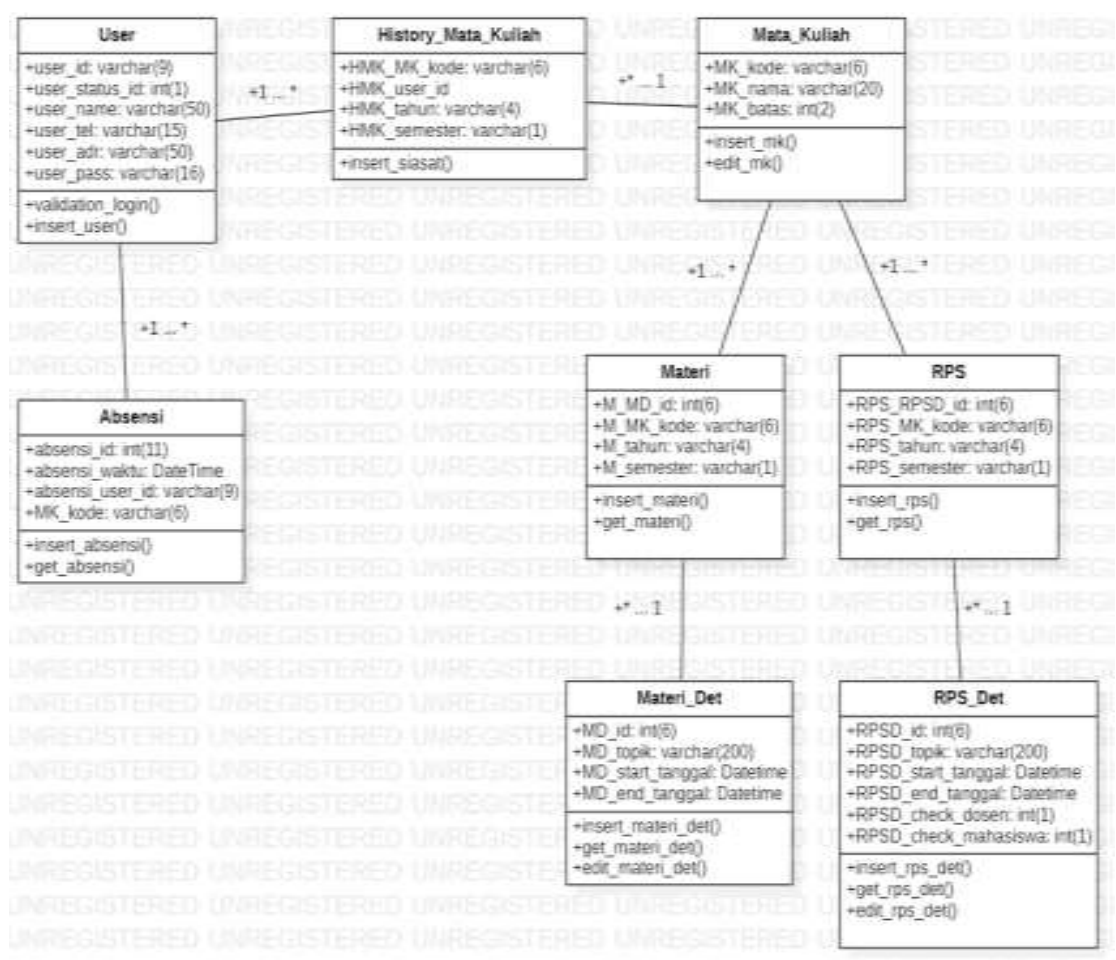

Figure 5 Class Diagram

\subsection{System Implementation}

Laravel Framework Can be applied in the development of an information system adjustment RPS with the results of system implementation In Figure 6 illustrates the data login interface used for verification before entering the system. the user enters the email and password, then the application will process the input from the user by matching it with the database. If the email and password is valid then the application will go to the dashboard page, if the email and the password is wrong, the system will redisplay the login page

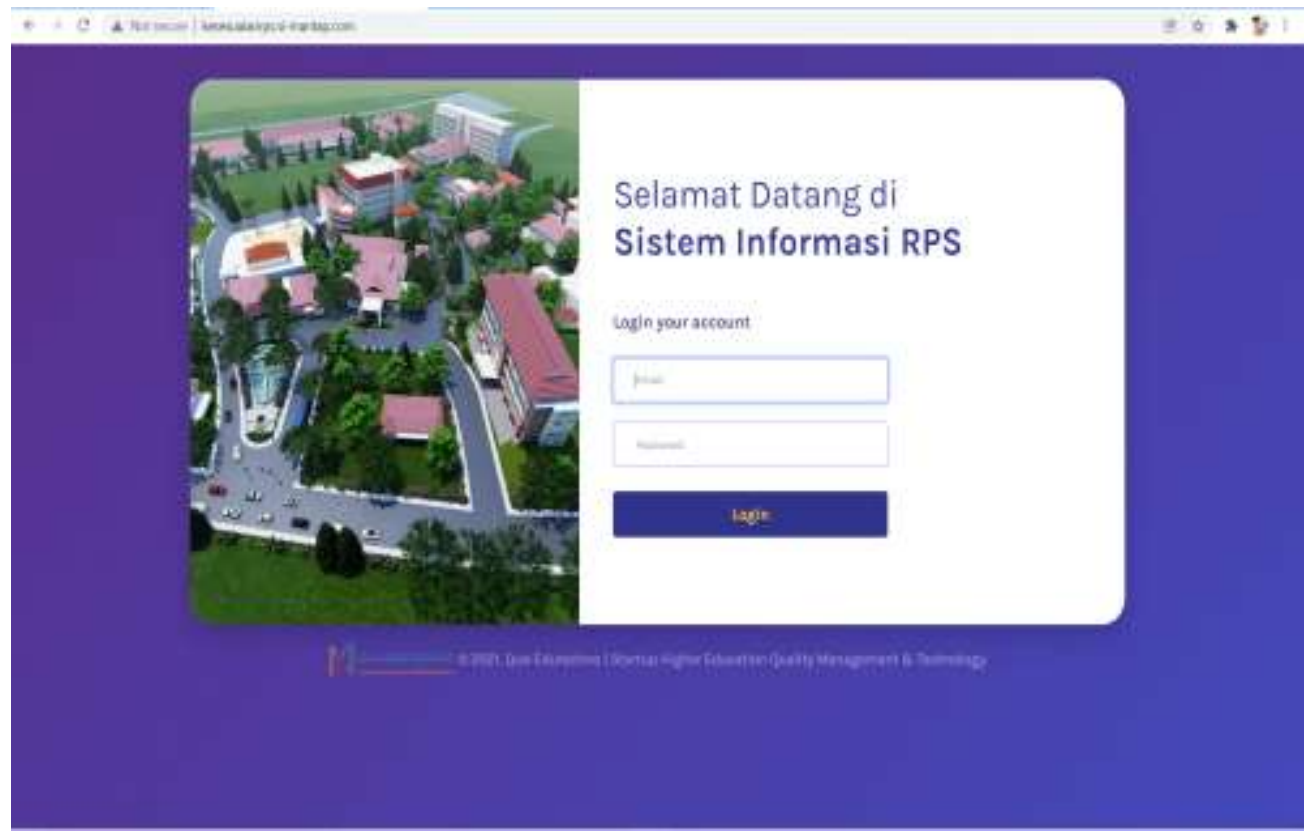

Figure 6 Login page 


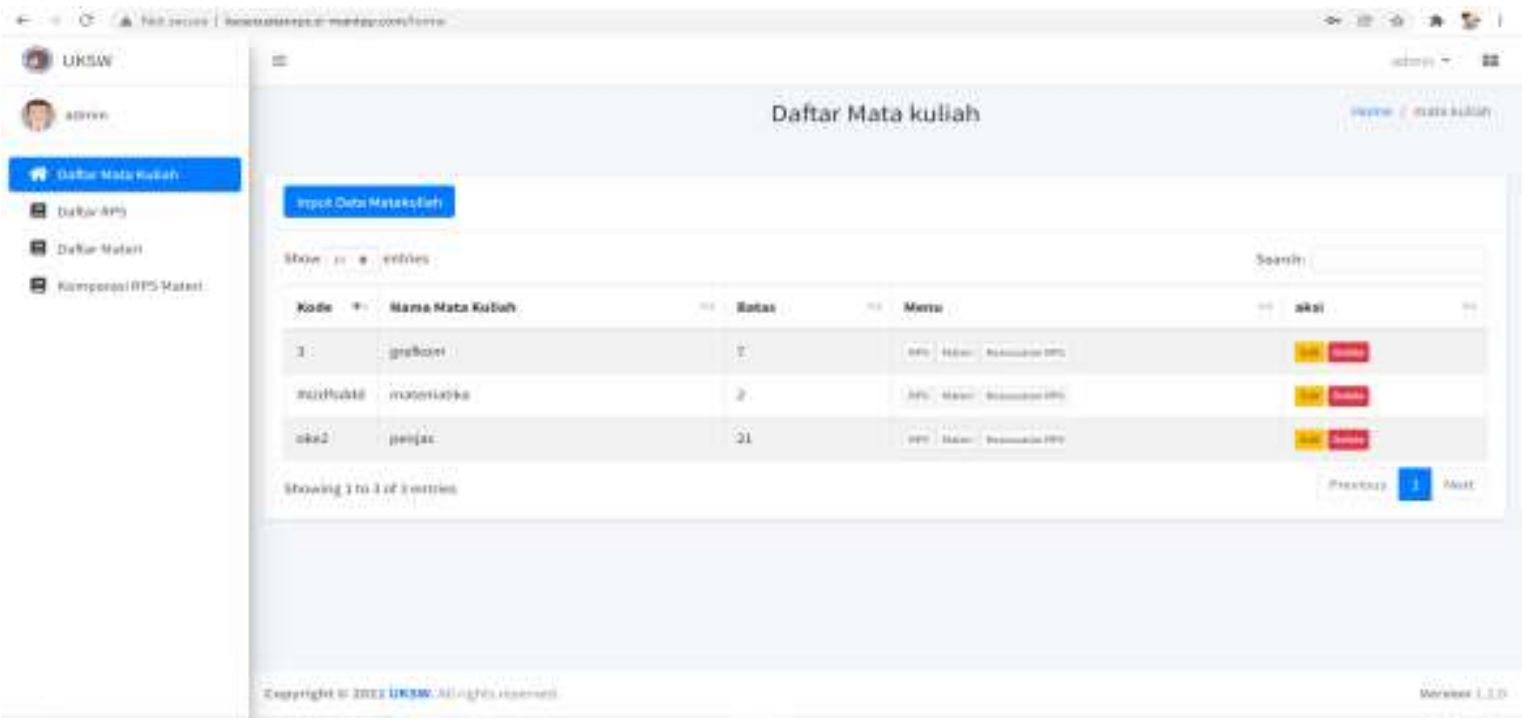

Figure 7 Page List of Subjects

Figure 7 shows the menu for a list of courses, the user can enter data eye lectures, change lecture data, and delete lecture data available menus to go to RPs, materials, and RPS compatibility.

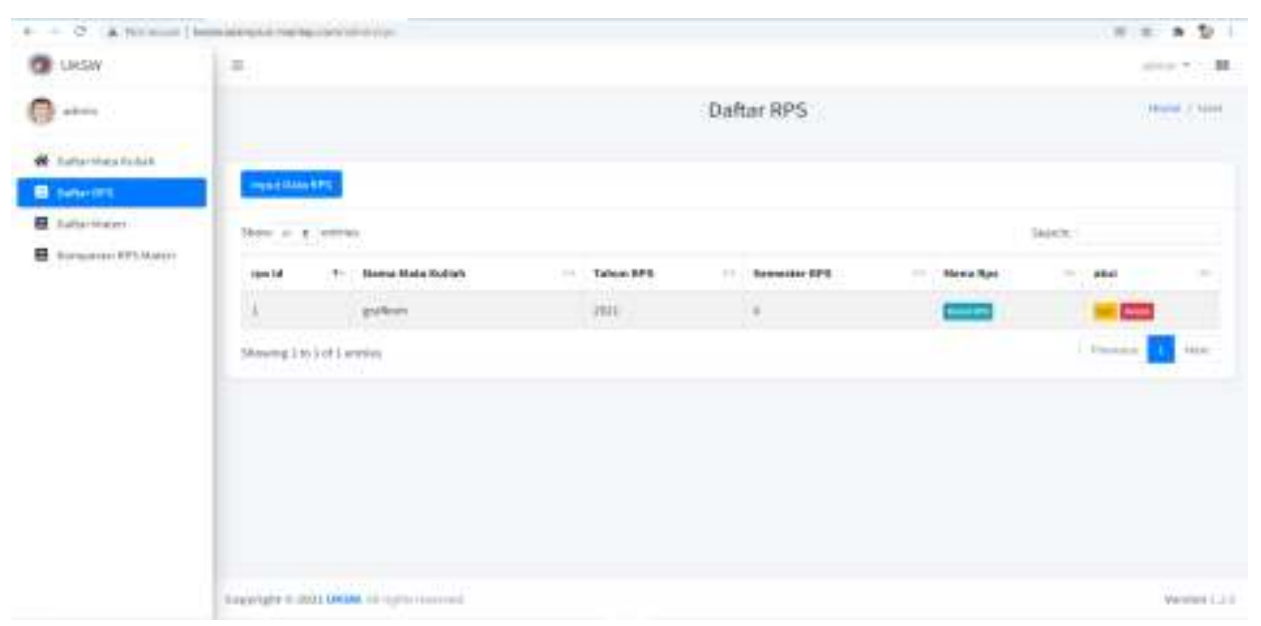

Figure 8 RPS List Page

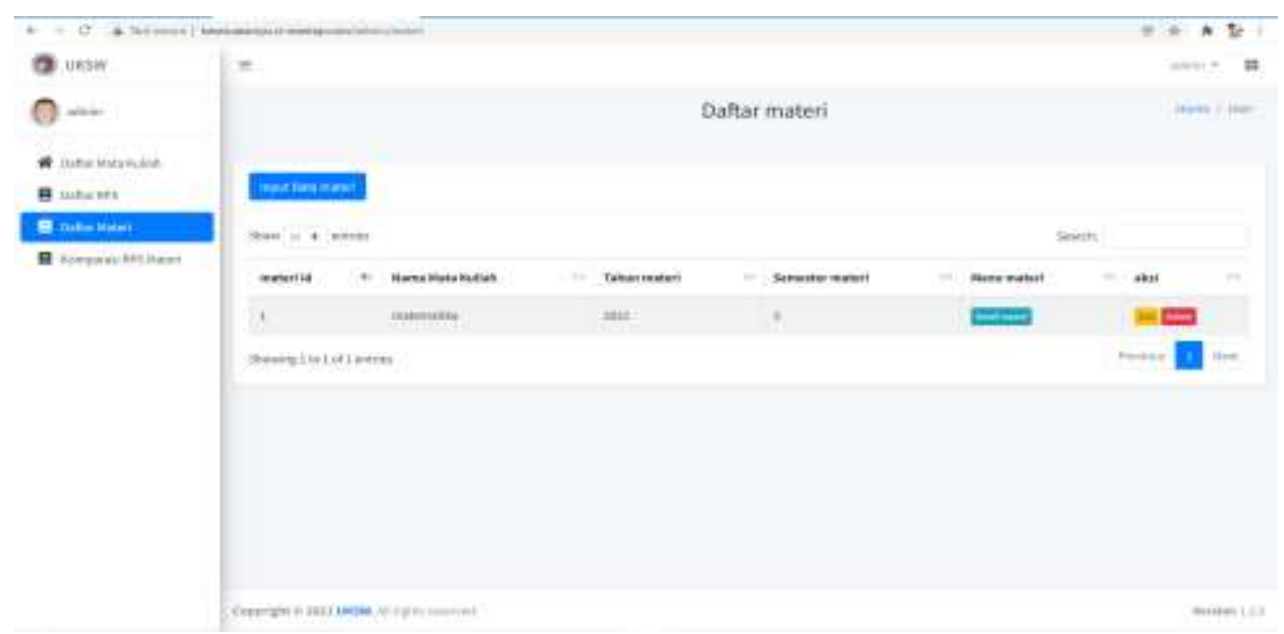

Figure 9 Material List Page 
Figure 8 and Figure 9 are pages for the RPs list and material pages, in each page, the user can enter data, edit data, and delete existing data. There are buttons for rps details and material details to enter detailed data.

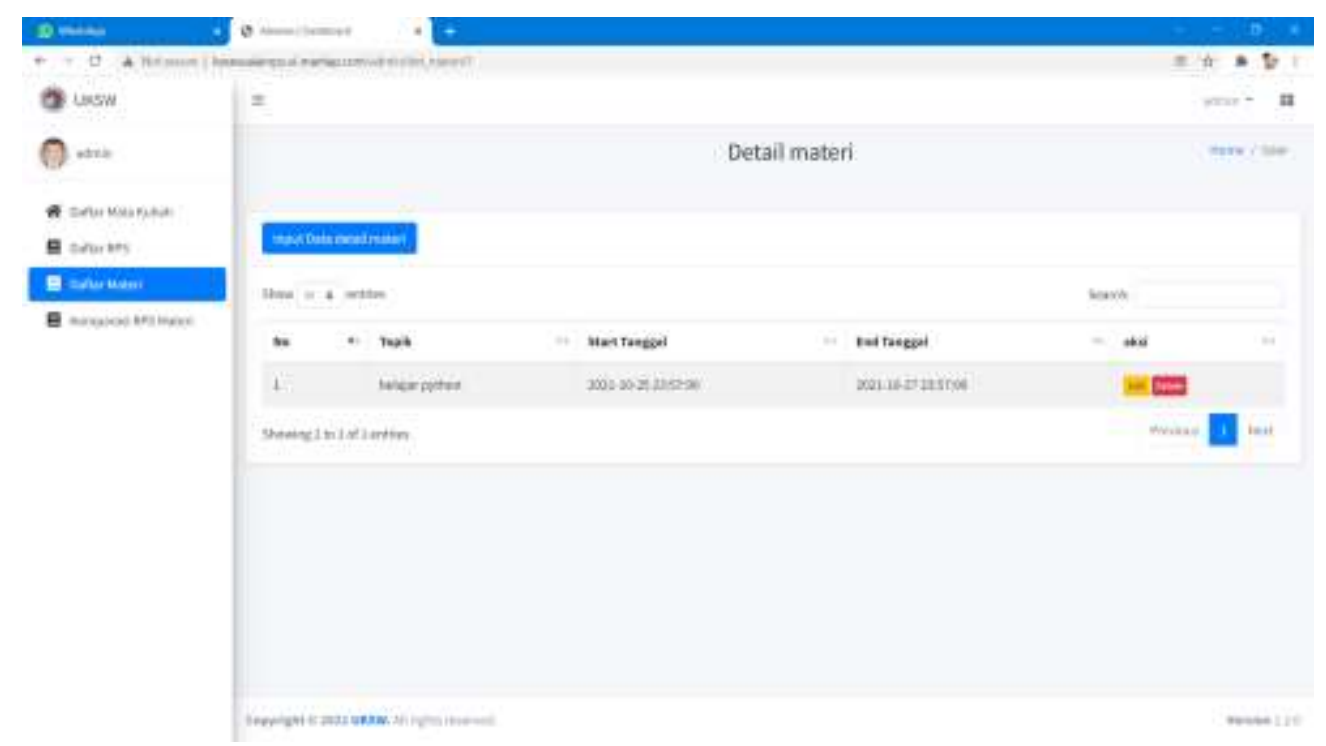

Figure 10 Material Details

In Figure 10 the user enters material details in the form of a topic, the start of the material, and the end of the material. In the details of this material, the user can also replace data and delete existing data.

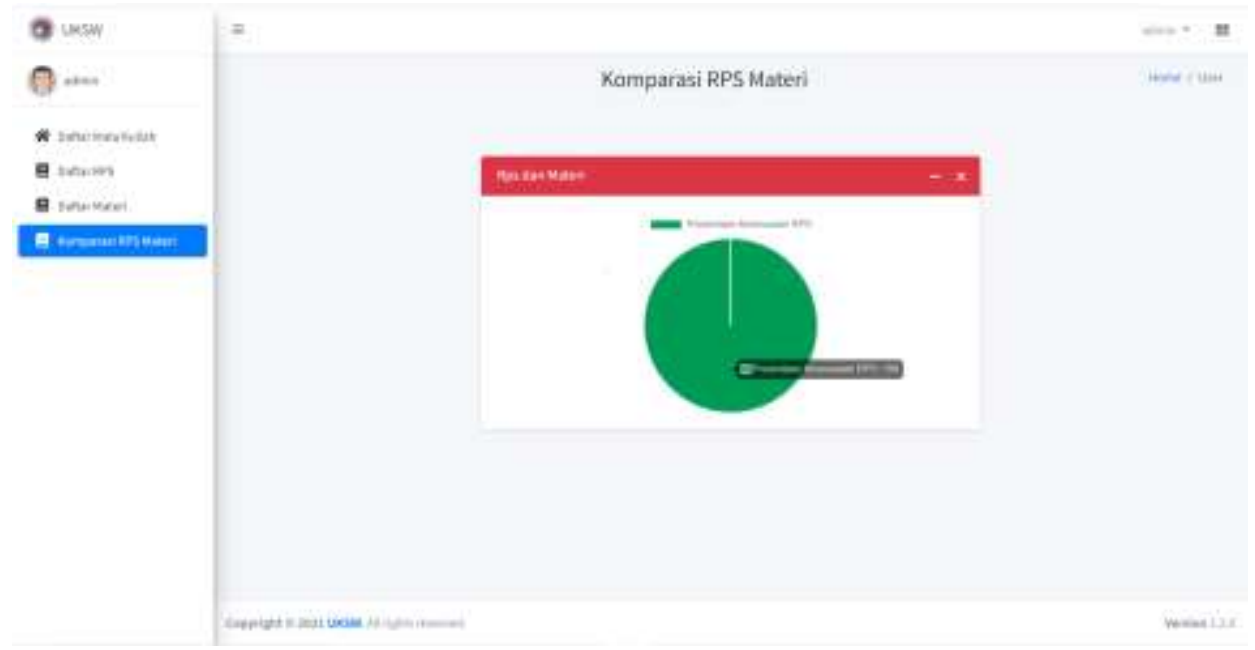

Figure 11 Comparison of RPS and Materials

Figure 11 is a page for processing materials and RPs to produce the percentage of similarity between material data and RPs data. The presentation is displayed in the form of a pie chart and the data used is data taken from the database.

\subsection{Software Testing}

At the stage or application which aims to get errors or errors in the application being tested. The purpose is to find out whether the application of the RPS conformity information system has met the criteria in accordance with to design of the application. The application test uses a black-box test that focuses on the requirements being tested, namely equivalence partitioning where application testing is carried out by dividing the input data and from the application unit or software into several pieces of data from which the test case can be described (Hidayat, 2019). In principle, test problems are designed to cover each partition at least once. The method used is aimed at defining the test problems revealed by the error class, thereby reducing the number of test problems that must be developed. 


\begin{tabular}{|l|l|l|l|}
\hline Class Test & Item Test & Type of Testing & Result \\
\hline Register User & Input Registration Form & Black Box & Valid \\
\hline Login User & Input Login User & Black Box & Valid \\
\hline \multirow{5}{*}{ Course Data } & Displays a list of courses & Black Box & Valid \\
\cline { 2 - 4 } & View a list of courses & Black Box & Valid \\
\cline { 2 - 4 } & Changes the list of courses & Black Box & Valid \\
\cline { 2 - 4 } & $\begin{array}{l}\text { Delete a list of courses } \\
\text { lectures }\end{array}$ & Black Box & Valid \\
\hline \multirow{5}{*}{ Data RPS } & Displaying data RPS & Black Box & Valid \\
\cline { 2 - 4 } & View data RPS & Black Box & Valid \\
\cline { 2 - 4 } & Change Data RPS & Black Box & Valid \\
\cline { 2 - 4 } & Deleting data RPS & Black Box & Valid \\
\hline & showing the data material & Black Box & Valid \\
\hline & View data material & Black Box & Valid \\
\cline { 2 - 3 } & Change material data & Black Box & Valid \\
\cline { 2 - 3 } & Deleting Material data & Black Box & valid \\
\hline RPS adjustment function & Can display data & Black Box & Valid \\
\hline
\end{tabular}

\section{Conclusion}

Based on the results of research and discussions that have been carried out, the use of the Laravel framework using the R\&D method can be applied in developing simple application systems that do not require repeated stages when building applications. In this study, the implementation of an information system adjustment using the web-based Research and Development method can provide effectively and efficiency and produce accurate output in comparison of material with the existing RPs, the Black Box method based on Equivalence Partitions can help the process of making test cases, quality tests and find undetected errors caused by typing errors.

\section{References}

[1] Hidayat, T., \& Putri, H. D. (2020). Pengujian Portal Mahasiswa pada Sistem Informasi Akademik (SINA) menggunakan Black Box Testing dengan Metode Equivalence Partitioning dan Boundary Value Analysis.

[2] Husaini, M. (2017). Pemanfaatan teknologi informasi dalam bidang pendidikan (e-education). MIKROTIK: Jurnal Manajemen Informatika, 2(1).

[3] Indrawan, Y. A. A. (2019). Perancangan Sistem Informasi Instrumen Kurikulum dan Evaluasi RPS Studi Kasus: Program Studi Sistem Informasi. Kurawal-Jurnal Teknologi, Informasi dan Industri, 2(1), 12-22.

[4] Johan, G. M. (2018). Analisis kesalahan berbahasa indonesia dalam proses diskusi siswa sekolah dasar. Jurnal Pendidikan Bahasa dan Sastra, 18(1), 136-149.

[5] Muhsinin, U., \& Fatmawati, K. (2020). Validitas dan Praktikalitas Rencana Pembelajaran Semester (RPS) Terintegrasi Research Based Learning. Jurnal Ilmiah Universitas Batanghari Jambi, 20(1), 201-206.

[6] Nurdin, S. (2018). Pengembangan kurikulum dan rencana pembelajaran semester (RPS) berbasis KKNI di perguruan tinggi. Al-Fikrah: Jurnal Manajemen Pendidikan, 5(1), 21-30.

[7] Putra, A. H., Pramana, D., \& Srinadi, N. L. P. (2019). Sistem Manajemen Arsip Menggunakan Framework Laravel dan Vue. Js (Studi Kasus: BPKAD Provinsi Bali). Jurnal Sistem dan Informatika (JSI), 13(2), 97-104.

[8] Rumetna, M. S., Lina, T. N., \& Santoso, A. B. (2020). Rancang Bangun Aplikasi Koperasi Simpan Pinjam Menggunakan Metode Research And Development. Simetris: Jurnal Teknik Mesin, Elektro dan Ilmu Komputer, 11(1), 119-128.

[9] Syafarina, G. A., \& Setiawan, A. (2019). Perancangan Aplikasi Rencana Pembelajaran Semester (RPS) Untuk Meningkatkan Pencapaian Pembelajaran bagi Dosen. Technologia: Jurnal Ilmiah, 10(4), 202-206.

[10] Wijonarko, D., \& Budi, F. W. S. (2019). Implementasi Framework Laravel Dalam Sistem Pendaftaran Mahasiswa Baru Politeknik Kota Malang. Jurnal Informatika dan Rekayasa Elektronik, 2(2), 35-42. 